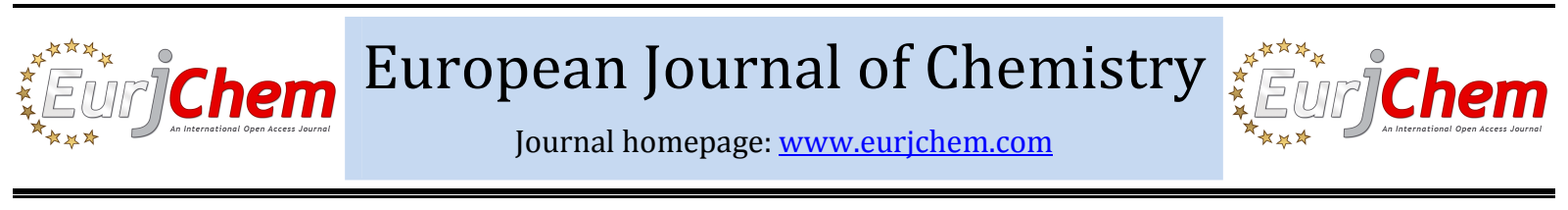

\title{
Oxonium heterocyclic quinone in the synthesis of some cyanine dyes and their antimicrobial activity
}

\author{
Maha Mobaruk Gomaa \\ Chemistry Department, Faculty of Science, Aswan University, Aswan, 81528, Egypt
}

*Corresponding author at: Chemistry Department, Faculty of Science, Aswan University, Aswan, 81528, Egypt. Tel.: +2.097.2305300. Fax: +2.012.2811224. E-mail address: mahamobarak81@yahoo.com (M.M. Gomaa).

\section{ARTICLE INFORMATION}

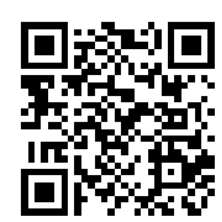

DOI: 10.5155 /eurjchem.5.3.463-468.973

Received: 17 November 2013

Received in revised form: 01 March 2014

Accepted: 10 March 2014

Online: 30 September 2014

\section{KEYWORDS}

Oxonium

Synthesis

Cyanine dyes

Visible spectra

Photosensitizers

Antimicrobial activity

\section{Introduction}

Cyanine dyes have found various applications in different fields, such as antimicrobial agents [1-4], photographic sensitizers, heat developable photosensitizing materials [5-7], and color photography [8]. Cyanine dyes also used as optical recording materials [9-15], in manufacturing of blue filter to laminate of an organic electroluminescent element, and color filter showed highly pure light emission [16] and antioxidants [17]. Cyanine dyes are colorant compounds used in staining of internal limiting membrane (ILM) [18] and used as fluorescent dyes in DNA detection [19-23]. Quinone derivatives are widely used as fungicides [24,25], and antibacterial agent [25-29]. This paper reports the synthesis and characterization of a series of new monomethine, trimethine and styrylmethine cyanine dyes, and also their structure-property relationship of these dyes from their visible absorption spectra.

\section{Experimental}

\subsection{Instrumentation}

All melting points are uncorrected. Elemental analysis was carried out at the Micro Analytical Center (Cairo University). The IR (KBr) spectra were determined with Perkin-Elmer Infrared 127B Spectrophotometer (Cairo University). ${ }^{1} \mathrm{H}$ NMR spectra were recorded with a Bruker AMX-250 spectrometer. The electronic absorption spectra were recorded within the wavelength range (350-700 $\mathrm{nm}$ ) on $6405 \mathrm{UV}$-Visible recording spectrophotometer, Faculty of Science, Aswan, Egypt. Mass spectra were recorded on an HPMs 6988 spectrometer (Cairo University).

\subsection{Synthesis of 2-acetyl-3-amino-1,4-naphthoquinone (2)}

This compound was prepared according to references described earlier (Scheme 1) [30,31].

\subsection{Synthesis of $N$-(3-acetyl 1,4-dioxo-1,4-dihydro naphthalen-2yl)acetamide (3)}

A pure sample of compound $\mathbf{2}$ was dissolved in acetic anhydride and the reaction mixture was refluxed for 3-5 h, filtered, concentrated and cooled. The product $\mathbf{3}$ was precipitated on dilution with water and crystallized from ethanol (Scheme 1). Color: Red. Yield: 80\%. M.p: 258-260 ${ }^{\circ} \mathrm{C}$. FT-IR (KBr, v, cm-1): 3400-3100 (NH), 1713-1620 (Acyclic $\mathrm{C}=0$ ), 1650 (Quinone ring), 1355 (C-N). ${ }^{1} \mathrm{H}$ NMR (400 MHz, DMSO- $\left.d_{6}, \delta, \mathrm{ppm}\right):$ 7.89-7.26 (m, $\left.4 \mathrm{H}, \mathrm{Ar}-\mathrm{H}\right), 6.97(\mathrm{~s}, 1 \mathrm{H}, \mathrm{NH})$, $2.54\left(\mathrm{~m}, 6 \mathrm{H}, 2 \mathrm{CH}_{3}\right)$. MS (El, $\left.m / z\right): 257,59$. Anal. calcd. for $\mathrm{C}_{14} \mathrm{H}_{11} \mathrm{NO}_{4}$ : C, 65.36; $\mathrm{H}, 4.28$; N, 5.44. Found: $\mathrm{C}, 65.36$; H, 4.27; N, $5.66 \%$. 
<smiles>O=C1C=CC(=O)c2ccccc21</smiles>

(1)

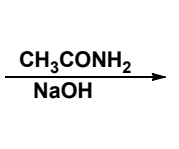<smiles>CC(=O)C1=C(N)C(=O)C(C(C)=O)c2ccccc21</smiles>

(2)<smiles>CC(=O)NC1=C(C(C)=O)C(=O)c2ccccc2C1=O</smiles>

(3)<smiles></smiles><smiles></smiles>

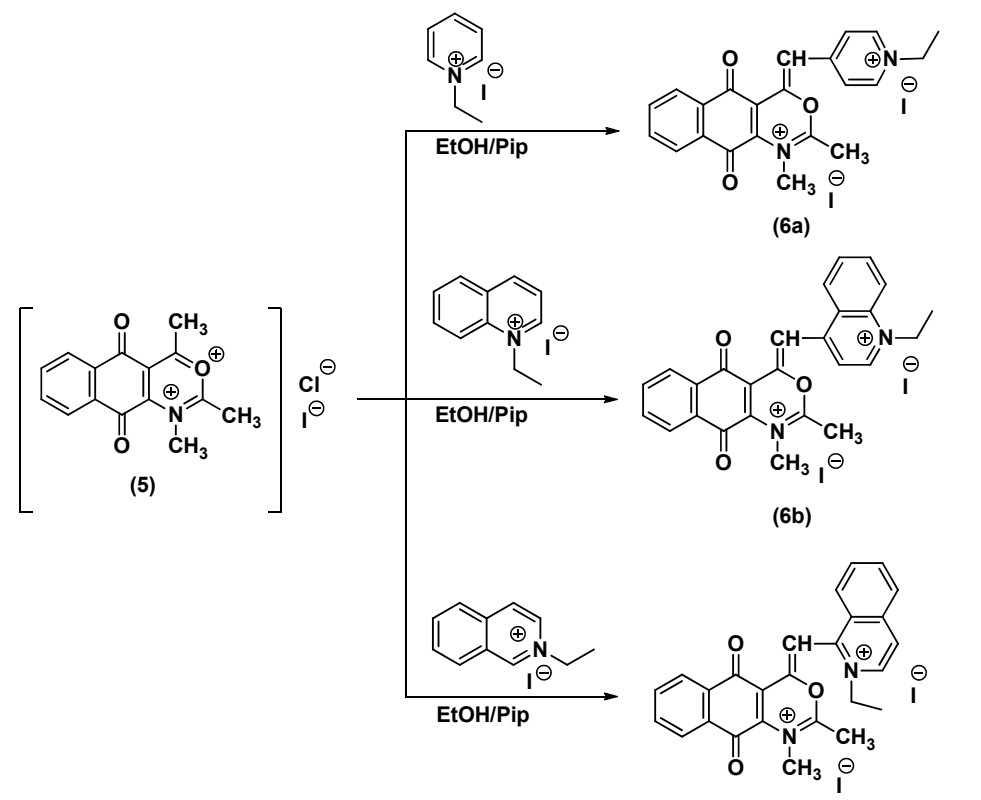

(6c)

Scheme 1

\subsection{Synthesis of 2,4-dimethyl-5,10-dioxo-5,10-dihydro naphtho[2,3-d][1,3]oxazin-3-ium chloride (4)}

A pure sample of compound $\mathbf{3}$ was dissolved in ethanol (30 $\mathrm{mL})$, and then hydrochloric acid $(1 \mathrm{~mL})$ was added. The reaction mixture was refluxed for $2 \mathrm{~h}$; filtered hot, concentrated and cooled. The product $\mathbf{4}$ was precipitated on dilution with water and crystallized from ethanol (Scheme 1). Color: Brownish red. Yield: $75 \%$. M.p: $217-220{ }^{\circ} \mathrm{C}$. FT-IR (KBr, v, cm1): 2921 (Chloride salt), 1634 (Quinone ring), 1480 (C=N), 1350 (C-N), 1150 (C-O-C cyclic). ${ }^{1} \mathrm{H}$ NMR (400 MHz, DMSO- $d_{6}, \delta$, ppm): 8.01-6.93 (m, 4H, Ar-H), $1.69\left(\mathrm{~s}, 3 \mathrm{H}, \mathrm{CH}_{3}\right.$ at C4), 1.31 (s, $3 \mathrm{H}, \mathrm{CH}_{3}$ at $\mathrm{C} 2$ ). $\mathrm{MS}$ (El, $\left.m / z\right): 275.5,132$. Anal. calcd. for $\mathrm{C}_{14} \mathrm{H}_{10} \mathrm{NO}_{3} \mathrm{Cl}: \mathrm{C}, 60.98 ; \mathrm{H}, 3.62 ; \mathrm{N}, 5.08$. Found: $\mathrm{C}, 60.99 ; \mathrm{H}, 3.62$; N, 5.09\%.

\subsection{Synthesis of 1,2,4-trimethyl-5,10-dioxo-5,10-dihydro naphtho[2,3-d][1,3]oxazine-1,3-diium chloride iodide (5)}

A pure sample of compound $\mathbf{4}$ was suspended in excess of ethyl (methyl) iodide and heated in a sealed tube at $140{ }^{\circ} \mathrm{C}$ for 3 $\mathrm{h}$. The sealed tube was cooled, opened and the product $\mathbf{5}$ was collected, washed with ether and crystallized from ethyl alcohol to give brown crystals (Scheme 1). Color: Dark black. Yield: 70\% M.p.: $188-190^{\circ} \mathrm{C}$. FT-IR (KBr, v, cm-1): 1155 (C-O-C cyclic), $1489(\mathrm{C}=\mathrm{N}), 1633$ ( $\mathrm{C}=\mathrm{O}$, Quinone), 2917 (quaternary salt ), 1360 (C-N). ${ }^{1} \mathrm{H}$ NMR (400 MHz, DMSO- $\left.d_{6}, \delta, \mathrm{ppm}\right): 1.10$ (s, 3H, $\mathrm{CH}_{3}$ (Methyl iodide)), 3.53 (s, 6H, 2CH3), 7.43-8.52 (m, $4 \mathrm{H}, \mathrm{Ar}-$ H). MS (El, $m / z): 417.5,156$. Anal. calcd. for $\mathrm{C}_{15} \mathrm{H}_{13} \mathrm{NO}_{3} \mathrm{CII}: \mathrm{C}$, 43.11; H, 3.11; N, 3.35. Found: C, 43.10; H, 3.12; N, 3.35\%.

\subsection{Synthesis of compound 6a-c dyes}

An ethanolic solution of equimolar amount of compound $\mathbf{5}$ and 1-ethyl-[pyridinium, quinolinium and/or iso-quinolinium] salts $(0.01 \mathrm{~mol})$ were refluxed for $7-8 \mathrm{~h}$, in the presence of piperidine (3-5 drops), filtered hot, concentrated and acidified with acetic acid. The precipitated products after dilution with water filtered off and crystallized from ethanol to give the corresponding products (Scheme 1 and 2).

4-((1-Ethylpyridin-1-ium-4-yl)methylene)-1,2-dimethyl-5,10dioxo-5,10-dihydro-4H-naphtho(2,3-d)(1,3)oxazin-1-ium iodide (6a): Color: Red. Yield: $70 \%$. M.p: $223-225{ }^{\circ} \mathrm{C} . \mathrm{MS}$ (El, $\mathrm{m} / \mathrm{z}$ ): 614, 77. Anal. calcd. for $\mathrm{C}_{22} \mathrm{H}_{20} \mathrm{~N}_{2} \mathrm{O}_{3} \mathrm{I}_{2}: \mathrm{C}, 43.02 ; \mathrm{H}, 3.28 ; \mathrm{N}, 4.56$ Found: C, $42.93 ; \mathrm{H}, 3.20 ; \mathrm{N}, 4.43 \%$. 


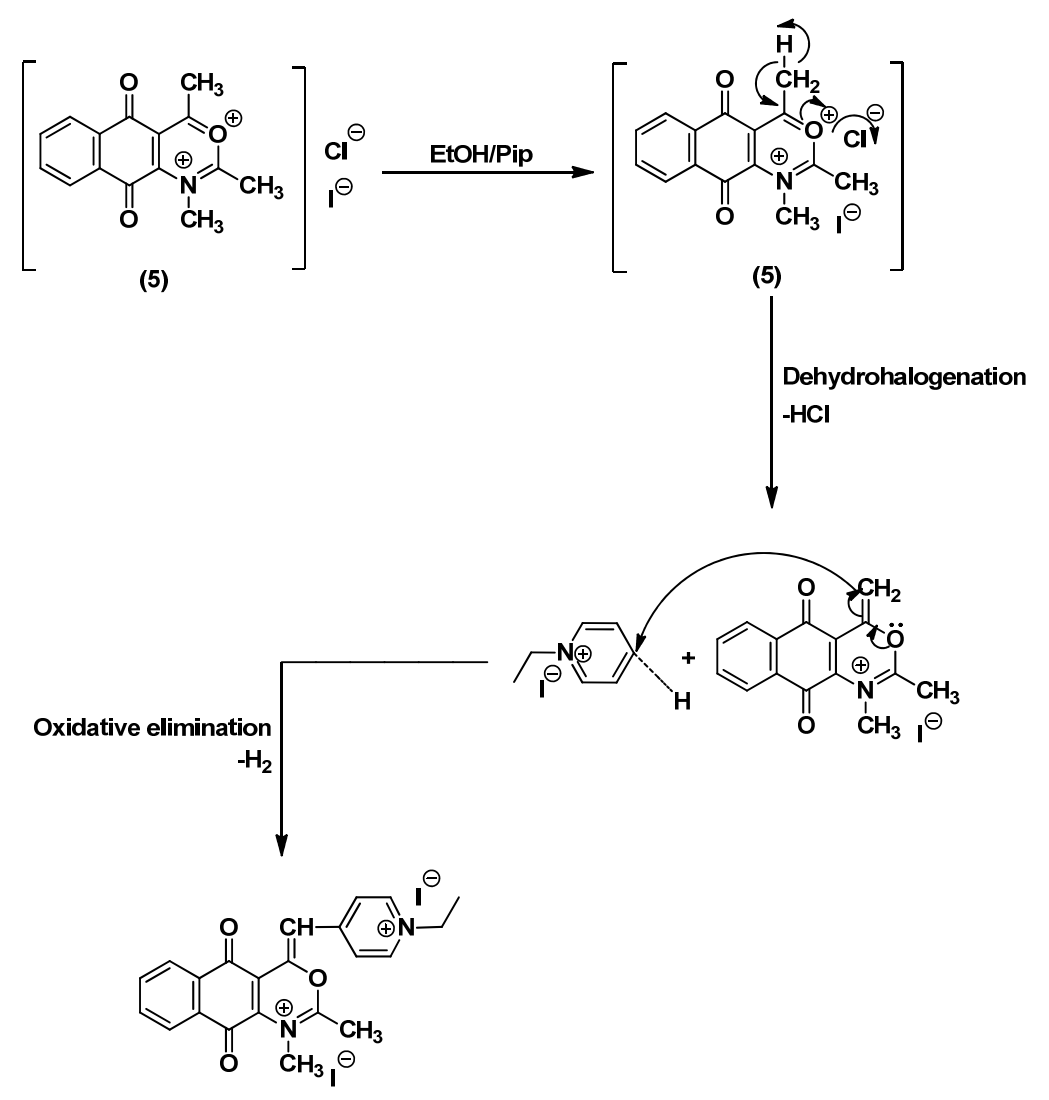

(6a)

Scheme 2

4-((1-Ethylquinolin-1-ium-4-yl)methylene)-1,2-dimethyl-5,10 -dioxo-5,10-dihydro-4H-naphtho(2,3-d)(1,3)oxazin-1-ium iodide (6b): Color: Deep red. Yield: 75\%. M.p: 203-205 ${ }^{\circ} \mathrm{C}$. FT-IR (KBr, $v, \mathrm{~cm}^{-1}$ ): 1650 (Quinone ring), $1487(\mathrm{C}=\mathrm{N}), 1360(\mathrm{C}-\mathrm{N}), 2800$ ( $\mathrm{N}-\mathrm{C}_{2} \mathrm{H}_{5}$ of heterocyclic group), 2950 (quaternary salt). ${ }^{1} \mathrm{H}$ NMR ( $\left.400 \mathrm{MHz}, \mathrm{DMSO}-d_{6}, \delta, \mathrm{ppm}\right): 1.02$ (s, $3 \mathrm{H}, \mathrm{CH}_{3}$ (methyl iodide)), $1.13\left(\mathrm{t}, J=6.9 \mathrm{~Hz}, 3 \mathrm{H}, \mathrm{CH}_{3}\right), 3.10\left(\mathrm{q}, 2 \mathrm{H}, \mathrm{CH}_{2}\right), 3.52\left(\mathrm{~s}, 3 \mathrm{H}, \mathrm{CH}_{3}\right)$, 6.50-8.83 (m, 11H, 10Ar-H+=CH). MS (El, $m / z): 664,156$. Anal. calcd. for $\mathrm{C}_{26} \mathrm{H}_{22} \mathrm{~N}_{2} \mathrm{O}_{3} \mathrm{I}_{2}$ : C, 47.01; $\mathrm{H}, 3.34 ; \mathrm{N}, 4.22$. Found: C, 46.90; H, 3.39; N, 4.27\%.

4-((2-Ethylisoquinolin-2-ium-1-yl)methylene)-1,2-dimethyl5,10-dioxo-5,10-dihydro-4H-naphtho(2,3-d) (1,3)oxazin-1-iumiodide (6c): Color: Deep red. Yield: $85 \%$. M.p: $177-180^{\circ} \mathrm{C}$. MS (El, $m / z$ ): 664, 297. Anal. calcd. for $\mathrm{C}_{26} \mathrm{H}_{22} \mathrm{~N}_{2} \mathrm{O}_{3} \mathrm{I}_{2}: \mathrm{C}, 47.01 ; \mathrm{H}$, 3.34; N, 4.22. Found: C, 46.95; H, 3.30; N, 4.23\%.

\subsection{Synthesis of 4-(2,2-diethoxyethyl)-1,2-dimethyl-5,10- dioxo-5,10-dihydronaphtho $(2,3-d)(1,3)$ oxazine-1,3-diium chloride iodide (7)}

A mixture of the quaternary compound $5(0.01 \mathrm{~mol})$ and ( $0.01 \mathrm{~mol})$ of triethyl-ortho-formate was dissolved in ethanol (50 mL) containing piperidine (3-5 drops) and refluxed for $4 \mathrm{~h}$, filtered hot to remove unreacted materials, concentrated to one half its initial volume, cooled, acidified with acetic acid, and precipitated by cold water, filtered off and crystallized from ethanol to give the corresponding product 7 (Scheme 3). Color: Brown. Yield: $68 \%$. M.p: $193-195^{\circ} \mathrm{C}$. FT-IR $\left(\mathrm{KBr}, v, \mathrm{~cm}^{-1}\right)$ : $1155-$ 1018 (C-O-C cyclic), 1227 (C-O ether), $1490(\mathrm{C}=\mathrm{N}), 1634$ (C=0 Quinone), 2919 (quaternary salt). ${ }^{1} \mathrm{H}$ NMR (400 MHz, DMSO- $d_{6}$, $\delta, \mathrm{ppm}$ ): 1.22 (s, 3H, $\mathrm{CH}_{3}$ (Methyl iodide)), $3.54\left(\mathrm{~s}, 3 \mathrm{H}, \mathrm{CH}_{3}\right.$ ), $1.25\left(\mathrm{t}, J=6.5 \mathrm{~Hz}, 6 \mathrm{H}, 2 \mathrm{CH}_{3}\right.$ of diethoxy ethyl), $3.85\left(\mathrm{q}, 4 \mathrm{H}, 2 \mathrm{CH}_{2}\right.$ diethoxy ethyl), $4.65(\mathrm{t}, J=6.9 \mathrm{~Hz}, 1 \mathrm{H}, \mathrm{CH}$ of diethoxy ethyl), $3.65\left(\mathrm{~d}, J=6.7 \mathrm{~Hz}, 2 \mathrm{H}, \mathrm{CH}_{2}\right.$ of diethoxy ethyl), $7.15-8.53(\mathrm{~m}, 4 \mathrm{H}$, Ar-H). MS (El, $m / z): 519.5,156$. Anal. calcd. for $\mathrm{C}_{20} \mathrm{H}_{23} \mathrm{NO}_{5} \mathrm{ClI}$ : C, 46.22; H, 4.46; N, 2.69. Found: C, 46.00; H, 4.40; N, 2.54\%.

\subsection{Synthesis of compound 8a-c dyes}

Equimolar amounts of compound $\mathbf{7}$ and 2-methyl quaternary salts $(\alpha(\gamma)$-picoline and $\backslash$ or quinaldine) ethyl iodide $(0.01 \mathrm{~mol})$ were dissolved in ethanol $(30 \mathrm{~mL})$ then piperidine (3-5 drops) was added. The reaction mixture was refluxed for 8 h, filtered hot, concentrated, cooled and acidified with acetic acid. The precipitated products (8a-c) after dilution with water were collected and crystallized from aqueous ethanol (Scheme 3).

4-((Z)-3-(1-Ethylpyridin-1-ium-2-yl)allylidene)-1,2-dimethyl5,10-dioxo-5,10-dihydro-4H-naphtho [2,3-d] [1,3] oxazin-1-ium iodide (8a): Color: Red. Yield: $65 \%$. M.p: $208-210{ }^{\circ} \mathrm{C}$. MS (El, m/z):640, 170. Anal. calcd. for $\mathrm{C}_{24} \mathrm{H}_{22} \mathrm{~N}_{2} \mathrm{O}_{3} \mathrm{I}_{2}$ : C, 45.02; H, 3.46; N, 4.38. Found: C, $45.20 ; \mathrm{H}, 3.45 ; \mathrm{N}, 4.33 \%$.

4-((Z)-3-(1-ethylquinolin-1-ium-2-yl)allylidene)-1,2-dimethyl-5,10-dioxo-5,10-dihydro-4H-naphtho[2,3-d][1,3]oxazin-1-ium iodide (8b): Color: Violet. Yield: $70 \%$. M.p: $>300{ }^{\circ} \mathrm{C}$. FT-IR (KBr, v, $\mathrm{cm}^{-1}$ ): 1151-1052 (C-O-C cyclic), 1359 (C-N), 1488 (C=N), $1595(\mathrm{C}=\mathrm{C}), 1632$ (C= 0 Quinone), 2917 (quaternary salt). ${ }^{1} \mathrm{H}$ NMR (400 MHz, DMSO- $d_{6}, \delta, \mathrm{ppm}$ ): 1.30 (s, 3H, $\mathrm{CH}_{3}$ (Methyl iodide)), $3.33\left(\mathrm{~s}, 3 \mathrm{H}, \mathrm{CH}_{3}\right), 0.88\left(\mathrm{t}, J=7.1 \mathrm{~Hz}, 3 \mathrm{H}, \mathrm{CH}_{3}\right), 4.25(\mathrm{q}$, $\left.2 \mathrm{H}, \mathrm{CH}_{2}\right), 6.54-8.90(\mathrm{~m}, 13 \mathrm{H}, 10 \mathrm{Ar}-\mathrm{H}+-\mathrm{CH}=)$. MS (El, $\left.m / z\right): 690$, 369. Anal. calcd. for $\mathrm{C}_{28} \mathrm{H}_{24} \mathrm{~N}_{2} \mathrm{O}_{3} \mathrm{I}_{2}$ : C, 48.72; $\mathrm{H}, 3.50 ; \mathrm{N}, 4.06$. Found: C, 48.60; H, 3.42; N, 4.09\%. 

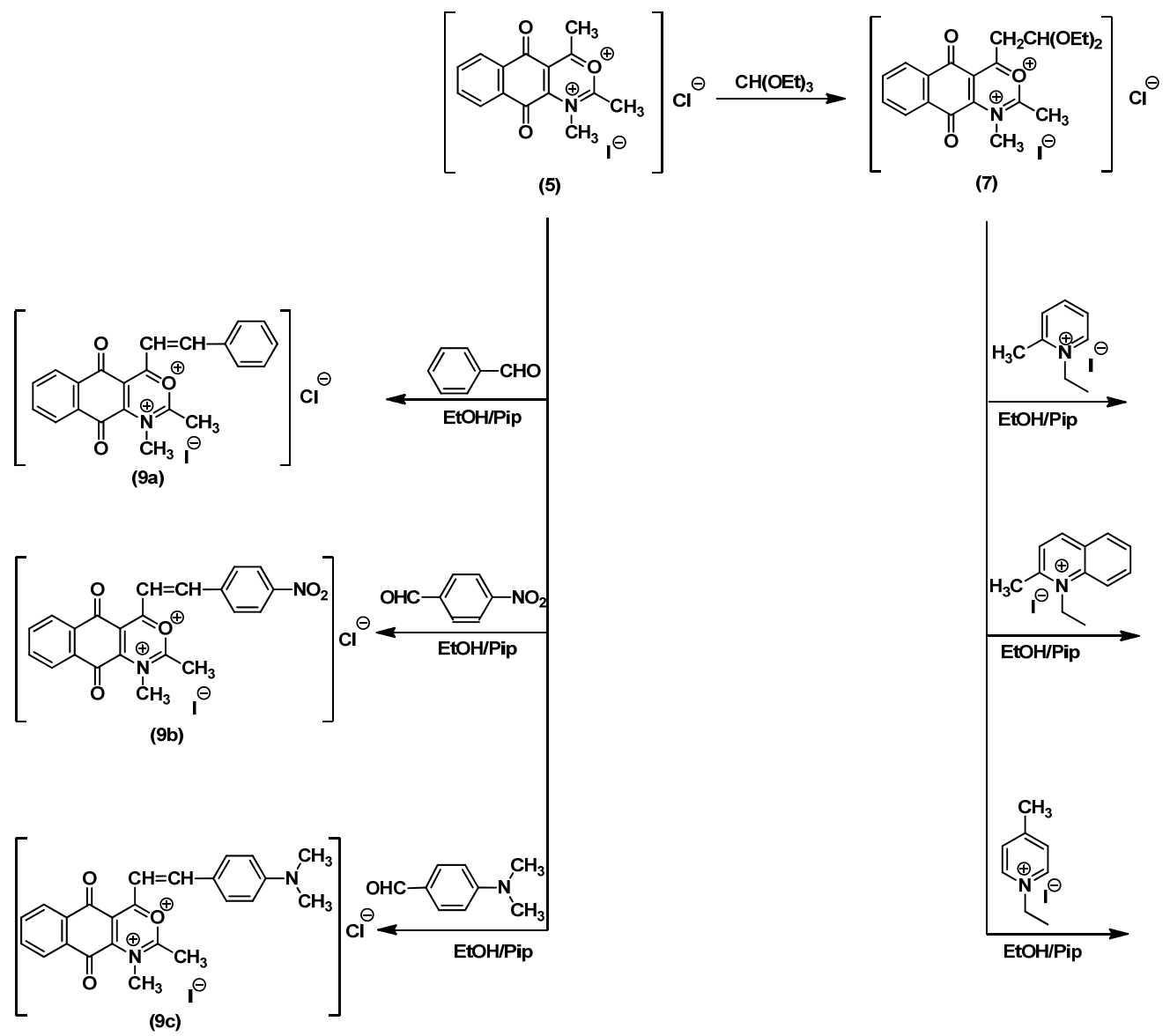

(7)

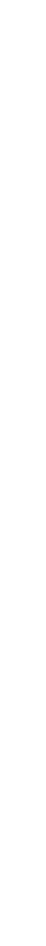

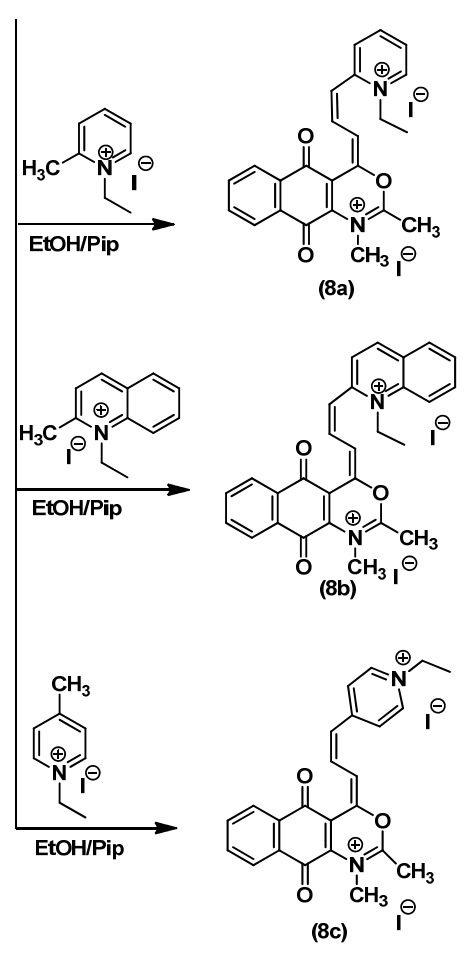

Scheme 3

4-((Z)-3-(1-ethylpyridin-1-ium-4-yl)allylidene)-1,2-dimethyl5,10-dioxo-5,10-dihydro-4H-naphtho [2,3-d] [1,3] oxazin-1-ium iodide (8c): Color: Red. Yield: $75 \%$. M.p: $128-130{ }^{\circ} \mathrm{C}$. MS (El, $m / z$ ):640, 297. Anal. calcd. for $\mathrm{C}_{24} \mathrm{H}_{22} \mathrm{~N}_{2} \mathrm{O}_{3} \mathrm{I}_{2}: \mathrm{C}, 45.02 ; \mathrm{H}, 3.46 ; \mathrm{N}$, 4.38. Found: C, $45.11 ; \mathrm{H}, 3.45 ; \mathrm{N}, 4.40 \%$.

\subsection{Synthesis of compound 9a-c dyes}

An equimolar amounts of heterocyclic quaternary salt (5, $0.01 \mathrm{~mol}$ ) and aromatic aldehydes (benzaldehyde, $p$-nitro benzaldehyde and/or $N$-dimethyl benzaldehyde $(0.01 \mathrm{~mol})$ were dissolved in absolute ethanol $(30 \mathrm{~mL})$, then piperidine $(1 \mathrm{~mL})$ was added. The reaction mixture was refluxed for 8-10 h, filtered hot, concentrated, acidified with acetic and then diluted with water. The precipitated styrylcyanines (9a-c) were filtered, washed several times with cooled water and then crystallized from the appropriate solvent (Scheme 3).

1,2-Dimethyl-5,10-dioxo-4-styryl-5,10-dihydronaphtho[2,3d][1,3]oxazine-1,3-diium chloride iodide (9a): Color: Red. Yield: 70\%. M.p.: $218-220^{\circ} \mathrm{C}$. MS (El, $\mathrm{m} / \mathrm{z}$ ): $505.5,156$. Anal. calcd. for $\mathrm{C}_{22} \mathrm{H}_{17} \mathrm{NO}_{3} \mathrm{ClI}: \mathrm{C}, 52.25 ; \mathrm{H}, 3.39$; N, 2.77. Found: $\mathrm{C}, 52.40 ; \mathrm{H}, 3.39$; $\mathrm{N}, 2.73 \%$.

1,2-Dimethyl-4-(4-nitrostyryl)-5,10-dioxo-5,10-dihydro naphtho(2,3-d)(1,3)oxazine-1,3-diium chloride iodide (9b): Color: Pale red. Yield: $82 \%$. M.p.: $>300{ }^{\circ} \mathrm{C}$. FT-IR $\left(\mathrm{KBr}, v, \mathrm{~cm}^{-1}\right)$ : 1160-1030 (C-O-C cyclic), 1350 (C-N), 1484 (C=N),1595 (C=C), 1650 (C=0 Quinone), 2957 (quaternary salt). ${ }^{1} \mathrm{H}$ NMR (400 MHz, DMSO- $d_{6}, \delta, \mathrm{ppm}$ ): 1.19 (s, 3H, $\mathrm{CH}_{3}$ (Methyl iodide)), 3.35 (s, $\left.3 \mathrm{H}, \mathrm{CH}_{3}\right), 8.20-7.21(\mathrm{~m}, 8 \mathrm{H}, \mathrm{Ar}-\mathrm{H}), 5.04-4.05(\mathrm{~m}, 2 \mathrm{H}, \mathrm{HC}=\mathrm{CH})$.
MS (El, $m / z): 550.5,369$. Anal. calcd. for $\mathrm{C}_{22} \mathrm{H}_{16} \mathrm{~N}_{2} \mathrm{O}_{5} \mathrm{ClI}$ : C, 47.98; H, 2.93; N, 5.09. Found: C, 47.89; H, 2.88; N, 5.20\%.

4-(4-(Dimethylamino)styryl)-1,2-dimethyl-5,10-dioxo-5,10dihydronaphtho[2,3-d][1,3]oxazine-1,3-diium chloride iodide (9c): Color: Brownish red. Yield: $63 \%$. M.p: $177-180{ }^{\circ} \mathrm{C}$. MS (El, $m / z$ ): 548.5, 504. Anal. calcd. for $\mathrm{C}_{24} \mathrm{H}_{22} \mathrm{~N}_{2} \mathrm{O}_{3}$ ClI: C, 52.52; $\mathrm{H}$, 4.04; N, 5.10. Found: C, 52.70; H, 4.15; N, 5.22\%.

\subsection{Antimicrobial studies}

The tested compounds $(3,4,5,6 a, 6 b, 6 c, 8 a, 8 b, 9 a$ and 9b) were dissolved in DMSO to give a final concentration (1 $\mathrm{mg} / \mathrm{mL}$ ). Susceptible sterile discs were impregnated by the tested substance $(50 \mu \mathrm{g} / \mathrm{disc})$ via a means of micropipette. The biological activity for each substance was tested on surfaceseeded nutrient agar medium with the prepared susceptible discs. Bacterial strains and the biological effect are shown in Table 1.

\section{Results and discussion}

\subsection{Synthesis}

Reaction of equimolar ratio of 1,2,4-trimethyl-5,10-dioxo5,10-dihydronaphtho [2,3-d] [1,3] oxazine-1,3-diium chloride iodide (5) with heterocyclic quaternary salts of pyridinium, quinolinium and isoquinolinium ethyl iodide in the presence of piperidine as basic catalysis afforded the desired compound 6a-c dyes (Scheme 1). 
Table 1. Biological activity of some newly synthesized compounds.

\begin{tabular}{|c|c|c|c|c|c|c|}
\hline \multirow[t]{2}{*}{ Compound } & \multicolumn{6}{|c|}{ Mean diameter inhibition zone (mm) } \\
\hline & $\begin{array}{l}\text { Bacillus } \\
\text { subtillus }\end{array}$ & $\begin{array}{l}\text { Escherichia } \\
\text { coli }\end{array}$ & $\begin{array}{l}\text { Staphylococcus } \\
\text { aureus }\end{array}$ & $\begin{array}{l}\text { Pseudomonas } \\
\text { aeruginosa }\end{array}$ & $\begin{array}{l}\text { Candida } \\
\text { albicans }\end{array}$ & $\begin{array}{l}\text { Aspergillus } \\
\text { niger }\end{array}$ \\
\hline 3 & 16 & 17 & 17 & 18 & 19 & 17 \\
\hline 4 & - & 11 & - & 14 & 15 & 15 \\
\hline 5 & 20.5 & 20 & 15 & 16 & 19.5 & 12 \\
\hline $6 a$ & 19 & 15 & 17 & 17 & 22.5 & 14.5 \\
\hline $6 b$ & 21.5 & 21 & 20 & 19.5 & 22 & 15 \\
\hline $6 c$ & 20 & 17 & 22 & 15.7 & 18.5 & 15.5 \\
\hline $8 a$ & 15 & 11 & 16 & - & 12 & 18 \\
\hline $8 b$ & 19 & 17 & 21 & 14 & 15 & - \\
\hline $9 a$ & 20 & 19 & 18 & 16.5 & 15 & 15 \\
\hline $9 \mathrm{~b}$ & 18 & 18 & 16 & 17 & 17 & 19 \\
\hline Standard * & 31.5 & 30 & 32 & 37.5 & 25 & 23 \\
\hline
\end{tabular}

$\mathrm{mg} / \mathrm{mL}$. Flucorai was used as standard for fungi at concentration $1 \mathrm{mg} / \mathrm{mL}$. Amikacin was tested as standard at concentration $1 \mathrm{mg} / \mathrm{mL}$ for Canadida albicans.

Table 2. The electronic absorption spectra of new synthesized cyanine dyes (6a-c), (8a-c) and (9a-c) in 95\% EtOH.

\begin{tabular}{|c|c|c|c|}
\hline Monomethine cyanine dyes ( $6 a-c)$ & $6 a$ & $6 \mathrm{~b}$ & 6c \\
\hline$\lambda_{\max }, \mathrm{nm}$ & 450 & 465 & 460 \\
\hline$\varepsilon_{\max }, \mathrm{mol}^{-1} . \mathrm{cm}^{-1}$ & 1871 & 1727 & 2250 \\
\hline Trimethine cyanine dyes (8a-c) & $8 a$ & $8 \mathbf{b}$ & 8c \\
\hline$\lambda_{\max }, \mathrm{nm}$ & 460 & $605,565,520$ & 465 \\
\hline$\varepsilon_{\max }, \mathrm{mol}^{-1} . \mathrm{cm}^{-1}$ & 1200 & $1100,1650,1200$ & 1440 \\
\hline Styryl cyanine dyes (9a-c) & $9 a$ & $9 \mathbf{b}$ & 9c \\
\hline$\lambda_{\max }, \mathrm{nm}$ & 445 & 405 & 460 \\
\hline$\varepsilon_{\max }, \mathrm{mol}^{-1} . \mathrm{cm}^{-1}$ & 1377 & 1770 & 1990 \\
\hline
\end{tabular}

Treating on the latter compound 6a-c by conc. $\mathrm{H}_{2} \mathrm{SO}_{4}$ resulted in liberating iodine vapor on warming. This is due to that the above reaction between the compound $\mathbf{5}$ and heterocyclic quaternary salts of pyridinium, quinolinium and/or isoquinolinium ethyl iodide was suggested to proceed through liberation of hydrogen chloride (dehydrohalogenation) and hydrogen molecule.

Additionally, interaction of equimolar ratios of compound $\mathbf{5}$ with triethyorthoformate in ethanol containing few drops of piperidine as a basic catalysis achieved the corresponding intermediate compound 7 (Scheme 3).

Further, reaction of intermediate compound $\mathbf{7}$ with active methyl heterocyclic quaternary salts $(\alpha(\gamma)$-picoline and /or quinaldine) ethyl iodide gave the corresponding compound $\mathbf{8 a}$ c dyes (Scheme 3). Treatment on the latter compound 8a-c by conc. $\mathrm{H}_{2} \mathrm{SO}_{4}$ resulted in liberating iodine vapor on warming. This is due to that the above reaction between the compound 7 and heterocyclic quaternary salts of $(\alpha(\gamma)$-picoline and /or quinaldine) ethyl iodide was suggested to proceed through elimination two molecules of ethanol and liberation of hydrogen chloride molecule.

Condensation reaction of equimolar ratios of compound $\mathbf{5}$ and benzaldehyde, $p$-nitrobenzaldehyde and/or $N$-dimethyl benzaldehyde between the active methyl group of the former compound and formyl group of the latter ones in the presence of piperidine as basic catalyst and ethyl alcohol as solvent gave the corresponding compound 9a-c dyes (Scheme 3).

The newly synthesized cyanine dyes (6a-c), (8a-c) and (9ac) are highly colored compounds, easily soluble in polar organic solvents given green fluorescence but sparingly soluble in nonpolar solvents and soluble in conc. $\mathrm{H}_{2} \mathrm{SO}_{4}$ liberating iodine vapor on warming.

\subsection{Spectral behavior}

The electronic absorption spectrum features $\left(\lambda_{\max }\right.$ and $\varepsilon_{\max }$ values) of the newly synthesized cyanine dyes (6a-c), (8a-c) and (9a-c) in ethanol solution are depicted in Table 2.

The visible absorption spectra of compound 6a-c dyes in $95 \%$ ethanol undergo bathochromic or hypsochromic shifts depending on the nature of the quaternary salts residue and their linkage position. Thus, the electronic absorption spectra of compound 6a which incorporating a heterocyclic of $N$-ethyl pyridin-4-ium, showed $\lambda_{\max }$ at $450 \mathrm{~nm}$. Substitution of a heterocyclic of $N$-ethyl pyridin-4-ium in compound $\mathbf{6 a}$ by a heterocyclic of $N$-ethylquinolin-4-ium in compound $\mathbf{6 b}$ resulted in a bathochromic shift of $\lambda_{\max }=15 \mathrm{~nm}$, so compound $\mathbf{6 b}$, exhibited $\lambda_{\max }=465 \mathrm{~nm}$. This is due to the more extensive $\pi$ delocalization and extra conjugation within the extra phenyl ring in quinolinium ring in compound $\mathbf{6 b}[32,33]$.

Additionally, changing the linkage position from 4-ium in compound $\mathbf{6 b}$ which incorporating a heterocyclic $N$-ethyl quinolin -4-ium to 1 -ium in compound $\mathbf{6 c}$ which incorporating a heterocyclic of $N$-ethyl isoquinolin-1-ium causes a hypsochromic shift of $\lambda_{\max }=5 \mathrm{~nm}$, so compound $6 \mathbf{c}$ showed $\lambda_{\max }=460 \mathrm{~nm}$. This is due to the more extensive $\pi$-delocalization within 4-ium rather than 1-ium linkage position (Table 2).

The visible absorption spectra of compound $\mathbf{8 a - c}$ dyes in 95\% ethanol showed absorption band undergo batho(hypso) chromically shifted depending upon the heterocyclic quaternary residue, and their linkage position. Thus, the absorption spectra of compound $\mathbf{8 a}$ quaternary heterocyclic residue of 1-ethyl pyridin-2-ium ethyl iodide showed $\lambda_{\max }=460$ nm. Substituting of heterocyclic quaternary residue 1-ethyl pyridin-2-ium ethyl iodide in compound $\mathbf{8 a}$ by quaternary heterocyclic residue of 1-ethyl quinolin-2-ium ethyl iodide in compound $\mathbf{8 b}$ resulted in strong bathochromic shift of $\lambda_{\max }=60$ $\mathrm{nm}$ concomitant with the increasing number of absorption bands, $\mathbf{8 b} \lambda_{\max }=520,565$, and $605 \mathrm{~nm}$. This is due to the more extensive $\pi$-delocalization within the extra phenyl ring in compound $\mathbf{8 b}$.

Additionally, changing the linkage position from 2-ium linkage position in compound $\mathbf{8 a}$, quaternary heterocyclic residue of 1-ethyl pyridin-2-ium ethyl iodide to 4 -ium in compound 8c, quaternary heterocyclic residue of 1-ethyl pyridin-4-ium ethyl iodide resulted in a remarkable bathochromic shift of $\lambda_{\max }=5 \mathrm{~nm}$, if compared with compound 8a, $\left(\mathbf{8 c}, \lambda_{\max }=465 \mathrm{~nm}\right)$. This is due to the increasing of the extension conjugation of 4-linkage pyridine moiety better than 2-linkage analogous (Table 2).

Finally, the visible absorption spectra of compound 9a-c dyes in 95\% ethanol showed absorption bands influenced by aryl substituents [34]. Thus, styryl cyanine dye 9a show single absorption band located at $\lambda_{\max }=445 \mathrm{~nm}$. Substituting benzaldehyde in dye $\mathbf{9 a}$ by $p$-nitro benzaldehyde in dye $\mathbf{9 b}$ resulted in a hypsochromic shift of $\lambda_{\max }=40 \mathrm{~nm}\left(\mathbf{9 b}, \lambda_{\max }=405\right.$ 
$\mathrm{nm})$. This is due to the strong electron withdrawing effect of $p$ $\mathrm{NO}_{2}$ group. Also, substituting $p$-nitro-benzaldehyde in dye $\mathbf{9 b}$ by $N$-dimethyl benzaldehyde in dye 9 c causes a bathochromic shift of $\lambda_{\max }=55 \mathrm{~nm},\left(9 \mathrm{c}, \lambda_{\max }=460 \mathrm{~nm}\right)$. This is due to the electron donating effect of two methyl groups (Table 2).

\subsection{Antimicrobial activity}

Structure-antimicrobial activity relation-ship for some selected newly synthesized quinone compounds $3, \mathbf{4}, \mathbf{5}, \mathbf{6 a - c}$, $\mathbf{8 a}, \mathbf{8 b}, \mathbf{9 a}$ and $\mathbf{9 b}$ were studied and determined against some bacterial and fungi strains (Table 1). The data obtained are expressed as size $(\mathrm{mm})$ of inhibition zone. Diameter of the inhibition zones were high (22-18 $\mathrm{mm})$, moderate $(17-12 \mathrm{~mm})$, slight (11-1 mm), no response (-). The final conclusion from this work is that these novel compounds showed significant antibacterial activity according to the following factors: (i) Increasing and/or decreasing conjugation in the dye molecule; (ii) Increasing and/or decreasing the number of the methine group; (iii) The presence of either electron donating and/or accepting group.

\section{Conclusion}

New unsymmetrical cyanine dyes have been prepared incorporating heterocyclic quinone and were identified by chemical and spectroscopic evidences (Elemental analysis, UVVis, IR, ${ }^{1} \mathrm{H}$ NMR and MS spectra). Also, antimicrobial activity of few selected compounds against some bacterial strains was tested.

\section{Acknowledgements}

I wish to express my sincere thanks and gratitude to all members of the Chemistry Department in Aswan University.

\section{References}

[1]. Sedov, K.; Garanzha, G. V.; Kulikova, L. Khim. Farm. Zh. 1976, 10(1), 66-70.

[2]. Shindy, H. A.; El-Maghraby, M. A.; Eissa, F. M. Dyes Pigments 2006, 170, 110-116.

[3]. Pawar, M. J.; Burungale, A. B.; Karale, B. K. Arkivoc 2009, 9, 97-107.

[4]. Thadhaney, B.; Sain, D.; Pernawat, G.; Talesara, G. L. Indian J. Chem. 2010, 49B, 368-373.

[5]. Abdelaal, R. M.; Koraiem, A. I. M.; El-Deen, N. S. Dyes Pigments 2004, 63, 301-314.

[6]. Delaey, E.; Van Laar, F.; De Vos, D.; Kamuhabwa, A.; Jacobs, P.; DeWitte, P. J. Photoch. Photobio. B 2000, 55(1), 27-36

[7]. Karatsu, T.; Yanai, M.; Yagai, S.; Mizukami, J.; Urano, T.; Kitmura, A. J. Photoch. Photobio. A 2005, 170, 123-129.

[8]. Jha, B. N.; Banerji, J. C. Dyes Pigments 1985, 6, 213-225.

[9]. Abdelaal, R. M.; Belal, A. A. M. Dyes Pigments 2005, 65, 129-136.

[10]. Sturnmer, D. M.; Heseltine, D. W.; James, T. H. Sensitizing and desensitizing dyes-the theory of photographic processes, $4^{\text {th }}$ edition, New York, Macmillan, 1977.

[11]. Dai, Z. F.; Peng, B. X. Dyes Pigments 1997, 35, 243-248.

[12]. Shindy, H. A. Dyes Pigments 2007, 75, 344-350.

[13]. Toshiyuki, S. J. Appl. Phys. A 2009, 96, 137-144.

[14]. Fukuda, T.; Kobashi, N. Chem. Lett. 2002, 35, 866-867.

[15]. Uchida, H.; Reddy, P. Y.; Nakamura, S.; Torn, T. J. Org. Chem. 2003, 68, 8736-8738.

[16]. Gacho, E. H.; Naito. T.; Inabe, T.; Fuknda, T.; Kobayashi, N. Chem. Lett. 2001, 120, 877-878.

[17]. Sarma, B. K.; Manna, D.; Minour, M.; Mugesh, G. J. Am. Chem. Soc. 2010, 132(15), 5364-5374.

[18]. Goldman, J. M.; Karp, C. L. Curr. Opin. Opthalomol. 2007, 18, 52-57.

[19]. Xiang-Han, Z.; Lan-Ying, W.; Zhi-Xiang, N.; Shi-Huan, T.; Zu-Xun, Z. Dyes Pigments 2008, 79, 205-209.

[20]. Hilal, H.; Taylor, J. Dyes Pigments 2007, 75, 483-490.

[21]. Timtcheva, I.; Maximova, V.; Deligeorgiev, T.; Zaneva, D.; Ivanov, I. J. Photoch. Photobio. A 2000, 130, 7-11.

[22]. Rosania, G. R.; Lee, J. W.; Ding, L. Yoon, H. S.; Chang, Y. T. J. Am. Chem. Soc. 2003, 125, 1130-1131.

[23]. Li, Q.; Kim, Y.; Namm, J.; Kulkarni, A.; Rosania, G. R.; Ahn, Y. H.; Chang, Y. T. Chem. Biol. 2006, 13, 615-623.

[24]. Harinath, B. B.; Subba, R. N. P. Indian Acad. Sci. A 1968, 67, 31-36.
[25]. Badran, M. M.; Moneer, A. A.; Refaat, H. M.; El-Malah, A. A. J. Chin Chem. Soc. 2007, 54, 469-478.

[26]. Mohareb, R. M.; Ho, J. Z.; Alfarouk, F. O. J. Chin. Chem. Soc. 2007, 54 1053-1066.

[27]. McKinney, J. D.; Honerzu, B. K.; Munoz-Elias, E. J.; Miczak, A.; Chen, B. Angew. Chem. 1999, 38, 2588-2590.

[28]. Van-Der, S.; Blunt, J.; Munro, M. Org. Lett. 2006, 8, 2059-2061.

[29]. Ali, M. M.; Ismail, M. M. F.; El-Gaby, M. S. A.; Zahran, M. A.; Ammar, Y. A Molecules 2000, 5, 864-873.

[30]. Soleiman, H. A.; Koraiem, A I.; Mohmoud, N. Y. J. Chin. Chem. Soc. Taip. 2005, 52, 119-124.

[31]. Gomaa, M. M.; El-Deen, N. S.; El-Kanzi, N. A. Eur. J. Chem. 2012, 3(4), 461-466.

[32]. Fayez, M.; Eissa, F. M. J. Chin. Chem. Soc. 2009, 56, 843-849.

[33]. Shindy, H. A.; Eissa, F. M.; El-Maghraby, M. A. Dyes Pigments 2002, 52, 79-87.

[34]. Dai, Z. F.; Peng, B. X. Dyes Pigments 1998, 36(3), 243-251. 